\title{
METHODOLOGICAL FRAMEWORK FOR ENERGY PROJECT EVALUATION IN RUSSIAN BUSINESS PRACTICE: IMPROVING THE OBJECTIVITY OF INVESTING DECISIONS
}

\author{
GALINA CHEBOTAREVA ${ }^{1} \&$ ANASTASIA DESYATKOVA ${ }^{2}$ \\ ${ }^{1}$ Academic Department of Energy and Industrial Enterprises Management Systems, \\ Ural Federal University, Russia \\ ${ }^{2}$ Rosseti Ural, Russia
}

\begin{abstract}
Investment projects in the energy sector are complex and super capital-intensive plans involve not only individual companies, but also cities and even whole regions. This makes it relevant to investigate the issue of objectivity in the evaluation of investment projects and investment decisions. Despite the basic concepts and evaluation procedures being spelled out in Russian legislation, certain methodological aspects are left to the discretion of energy companies. There is a serious problem of the lack of sufficient hands-on experience in effectiveness management in Russian energy companies under out-of-theordinary and fast-changing conditions. This further dents the objectivity of investment project evaluation. The article presents a summary of methods of evaluating the effectiveness of energy projects that are used in Russia and abroad. An expert analysis of the applicability of the methods was conducted on the basis of 15 criteria, including technical, social and economic, industry-specific aspects, sensitivity, impacts of risk etc. Based on the results of the analysis, the authors suggest their own method of evaluating the effectiveness of energy projects. The method supplements traditional investment calculations with ten new phases, including scenario forecasting of revenue, estimation of operating costs, analysis of risks on the basis of project sensitivity, measurement of technical and economic performance etc. The method was given a trial by Russia's largest grid company Rosseti. The calculations confirmed enhanced objectivity of investment decisions compared to an approach used previously. They served as the foundation for drafting methodological recommendations for the adoption of the method by the energy company.
\end{abstract}

Keywords: energy sector, project, investment, investment analysis, economic efficiency, investment decisions, risks, sensitivity analysis, expert assessment.

\section{INTRODUCTION}

The Russian energy sector has a number of peculiar features that have considerable influence on investment processes in the industry, including [1]-[4]:

- Unique social role (life support and development provisions for all sectors of the economy).

- High fuel intensity.

- Environmental matters.

- Advanced technologies and research intensity.

- A strong dependence of the sector's development on the level of advancement of its consumers etc.

This determines the high capital intensity of energy projects and long payback periods. These factors, along with relatively low rates of return, make the industry less attractive to investors [1]-[6]. This implies that standard ways of doing business in the Russian energy market are not applicable. 
Consequently, the development goals of the Russian energy sector generate an urgent task of building a fundamentally new methodological framework for evaluating the effectiveness and efficiency of projects being implemented in the sector. Experts in Chebotareva [7] suggest that it should take into account the specific character of the industry and eliminate the drawbacks of the existing methods and guidelines [8]-[10]. That would result in greater objectivity of investment decisions, especially when alternative energy projects and scenarios are explored. Creating such an approach and testing it in practice is the main objective of this study.

The structure of this article is determined by the above-identified research and application problem and the objective of this study. Part two presents an overview and a comparative expert analysis of the most common methods of evaluating the efficiency and effectiveness of industrial projects. Building upon the produced methodological guidelines, the authors have designed a specialized approach to the evaluation of the efficiency of energy projects that is presented in part three. The approach consists of ten phases and is supplemented with the metric of maximum negative cash balance. The approach delivers a visualization of the calculations performed. Part four of the article describes how the approach was tested in application to a substation retrofit project implemented by Rosseti. It also presents a comparison of the calculation results delivered by the new approach and the methodology currently in use at the company. Conclusions present a summary of the main outcomes of the article, substantiate the argument that the proposed approach ensures greater objectivity of investment decision making, and offer practical recommendations for its adoption by energy companies.

\section{METHODS OF ENERGY PROJECT EFFECTIVENESS EVALUATION}

The basic techniques that are adopted for evaluating the effectiveness and efficiency of capital-intensive energy projects both in Russia and abroad can be grouped into undiscounted and discounting ones [10]-[14]. Investment experts traditionally look at the following metrics [15]-[18]:

- In non-discount methods [17], [18]: net value, payback period.

- The most common discounting techniques are [19], [20]: net present value (NPV), profitability index, internal rate of return (IRR), discounted payback period (DPP), accounting rate of return.

Today, discounted measures of project worth are given priority when evaluating investment projects by Russian energy companies [8], [10]. Globally, however, a number of other techniques [21] have been adopted by the likes of Goldman Sachs [21], [22] and Ernst \& Young [22], along with the guidelines issued by the European Bank of Reconstruction and Development (EBRD), the World Bank [23], [24], cost-benefit analysis (CBA) [25], the Little-Mirrlees (LM) method [26], [27], and UNIDO [28], [29].

The methods applied by Goldman Sachs, Ernst \& Young, and the EBRD are essentially frameworks for creating a business plan of a project. The Goldman Sachs methodology, for example, uses official statistics, such as average prices of energy and construction materials, that are less prone to deliberate distortions. Ernst \& Young uses the adjusted present value for investments valuation [15]. The measure is a form of NPV and includes adjustments such as the cost of equity financing, something that many Russian companies do not resort to. The EBRD technique envisages the creation of business plans as well as evaluation of projects' effectiveness according to classical criteria.

The World Bank's technique appraises investments mainly from the perspective of social rather than commercial effectiveness [30]. A project is considered acceptable if it is sound, 
financially feasible and, most importantly, is in line with the goals declared by the UN. The technique uses such measures as NPV, DPP, and Bruno ratio that makes it possible to evaluate projects' effectiveness in terms of shadow prices reflecting net savings. It does, however, seem problematic to apply the Bruno ratio in Russia due to peculiarities of doing business in the national energy industry [2].

In order to make an investing decision, cost-benefit analysis is used to calculate the project's NPV and IRR over time. The limitations of the method are that it is not very accurate for long-term benefits, yields low-accuracy in a long-term perspective and it does not take into account non-commercial benefits and the effects of budget reprogramming on effectiveness.

The UNIDO method is a development of cost-benefit analysis [28]. It evaluates the commercial and community (social) effectiveness of projects. This approach highlights the production of goods, services and energy for consumption as the ultimate investment goal, so the costs and benefits of projects are measured in terms of consumption. The method calculates shadow prices on the basis of the characteristics of domestic consumption, or measures consumers' preparedness to pay for a good or service and uses aggregate consumption as a unit of measurement. The UNIDO method is broken down into five stages of project appraisal from a different angle. Taken in isolation, none of the stages can serve as a sufficient basis for investment decision making.

The LM method [26] is an alternative to the UNIDO technique. It is used to calculate the cost of all goods and services in international prices. If a product is only traded in the domestic market, a complex procedure is applied to convert domestic prices into international ones. Domestic prices and the price ratio are of secondary importance in the method.

Table 1: Comparative analysis of project evaluation methods.

\begin{tabular}{|c|c|c|c|c|c|c|c|c|}
\hline Area of analysis & $\begin{array}{c}\text { Goldman } \\
\text { Sachs }\end{array}$ & $\begin{array}{c}\text { Ernst \& } \\
\text { Young }\end{array}$ & EBRD & $\begin{array}{l}\text { World } \\
\text { Bank }\end{array}$ & CBA & UNIDO & LM & $\begin{array}{l}\text { Recommen- } \\
\text { dations for } \\
\text { Russia }\end{array}$ \\
\hline Purpose of analysis & \multicolumn{8}{|c|}{ Substantiation of investment project } \\
\hline Market & + & + & +1 & - & + & + & + & - \\
\hline $\begin{array}{l}\text { Technical/technological } \\
\text { factors }\end{array}$ & + & + & + & + & - & + & + & + \\
\hline Socio-economic & - & - & - & + & - & + & + & + \\
\hline Community & - & - & - & + & - & + & + & + \\
\hline Environment & - & - & + & + & - & + & - & - \\
\hline Economy & - & - & + & + & + & + & + & + \\
\hline Finances & + & + & + & + & + & + & + & + \\
\hline Time factor & + & + & + & + & + & + & + & + \\
\hline Inflation & + & + & + & + & + & + & + & + \\
\hline Risk & + & + & + & + & + & - & + & + \\
\hline Sensitivity & + & + & + & + & + & + & + & + \\
\hline Sectoral customization & - & - & $\begin{array}{c}\text { Small } \\
\text { business }\end{array}$ & - & - & $\begin{array}{c}\text { Manufac- } \\
\text { turing }\end{array}$ & - & Innovations \\
\hline $\begin{array}{l}\text { Adaptability to current } \\
\text { market conditions }\end{array}$ & + & + & + & + & - & - & - & - \\
\hline $\begin{array}{l}\text { Easy-to-understand } \\
\text { conclusions and clear } \\
\text { results }\end{array}$ & - & - & + & + & - & + & + & - \\
\hline
\end{tabular}

In order to critically analyze the applicability of the techniques described above in the Russian energy market, an expert group was created involving specialists with the investment 
directorate of Rosseti Ural, a subsidiary of Rosseti. The results of the analysis that are presented in Table 1 will be used when designing a new approach to project appraisal.

According to Rosseti Ural experts, the methods of UNIDO and the World Bank appear to be the most practicable for the energy sector. Their advantage is that they integrate technical, socio-economic, environmental, economic and financial analysis as well as the factors of time, inflation and sensitivity. These methods deliver conclusions that are easy to comprehend and evaluation results can be presented with visual clarity. Consequently, the new method should be built upon the evaluation of the classical investment measure of NPV and incorporate supplemental criteria and types of analysis, cases for scenarios and a choice of investment alternatives.

\section{PROPOSAL OF AN APPROACH FOR PROJECT EVALUATION AT ENERGY COMPANIES}

What makes the new approach different from the existing method is that it incorporates new stages of evaluation, including the calculation of additional metrics that, collectively, ensure the tailoring of the method for the energy industry and provide greater objectivity of project evaluation. The structure of the proposed method and its key stages are described in Table 2.

The main objective of the method is to optimize preparation procedures, improve the accuracy of expert appraisal and evaluation of projects and raise the quality of technical and economic proposals. When applied in practice, the proposed method should enable more effective resource use at energy companies and maintain the required level of power supply reliability.

A feature of this method is that stage seven of the traditional investment valuation method is enhanced with the criterion of maximum negative cash balance. It reflects the losses that can be incurred by the investor if the project is given up when the main capital expenditures have already been executed, but no cash flows have been generated yet. The inclusion of this metric is necessitated by the importance of appraising the maximum loss that could occur for the investor if the project is rejected.

A comprehensive evaluation of a project is supplemented with an analysis of specific risks on the basis of the methods of one-factor and multiple-factor analysis of sensitivity. The methods make it possible to consider the impact that possible combinations of the key effectiveness indicators have on the project under various scenarios. In the course of the analysis, the key indicators of the project in each scenario are compared to the baseline values.

The following assumptions are used in the course of energy project evaluation:

- Indicators of project effectiveness are calculated by cash flows in current prices (unadjusted for inflation).

- The project is considered subject to taxes envisaged by the existing tax laws.

- Operating capital needs are taken into account if stipulated by the project specifications.

\section{APPLICATION OF THE METHOD BY PJSC ROSSETI}

\subsection{Rosseti PJSC: Company profile}

Rosseti, public joint stock company (PJSC Rosseti) is an operator of energy grids in Russia and one of the largest electric companies in the world [31]. The company maintains 2.35 million $\mathrm{km}$ of power transmission lines, 507,000 substations with transformer capacity of more than $792 \mathrm{GW}$. In 2019, net power supply to consumers amounted to 763 billion $\mathrm{kWh}$. 
Table 2: Structure of the proposed method of energy project evaluation.

\begin{tabular}{|c|c|c|}
\hline No & Stage & Brief outline \\
\hline 1 & $\begin{array}{l}\text { Work out the key } \\
\text { characteristics of the project } \\
\text { and options for its } \\
\text { implementation, specify the } \\
\text { relevant technical solutions }\end{array}$ & $\begin{array}{l}\text { Describe the suggested technical solutions and } \\
\text { implementation options; suggest the launch date. The } \\
\text { subsequent stages are executed for each of the proposed } \\
\text { technical solutions }\end{array}$ \\
\hline 2 & Collect the input data & $\begin{array}{l}\text { - Macroeconomic indicators for better precisions of } \\
\text { scenario conditions (including long-term forecasts of } \\
\text { inflation and exchange rates). } \\
\text { - Project parameters that are stipulated by the investor and } \\
\text { are specified in the project brief. } \\
\text { - Other parameters that are determined by implementation } \\
\text { conditions. }\end{array}$ \\
\hline 3 & $\begin{array}{l}\text { Calculate capital expenditures } \\
\text { and working capital }\end{array}$ & $\begin{array}{l}\text { Evaluate total capital expenditures and working capital } \\
\text { required for project implementation }\end{array}$ \\
\hline 4 & Revenue forecast & Projections of revenue from sales generated by the project \\
\hline 5 & Confirm operating costs & $\begin{array}{l}\text { Evaluate operating costs that a component of the cost of } \\
\text { services delivered as part of the project }\end{array}$ \\
\hline 6 & Evaluate cash flows & Calculate net discounted cash flows \\
\hline 7 & $\begin{array}{l}\text { Evaluate measures of project } \\
\text { efficiency }\end{array}$ & $\begin{array}{l}\text { - Net cash flow. } \\
\text { - Net present value. } \\
\text { - Internal rate of return. } \\
\text { - Discounted payback period. } \\
\text { - Profitability index. } \\
\text { - Maximum negative cash balance. }\end{array}$ \\
\hline 8 & Risk analysis & $\begin{array}{l}\text { Analyze risks to the project by means of sensitivity } \\
\text { analysis }\end{array}$ \\
\hline 9 & $\begin{array}{l}\text { Evaluate technical and } \\
\text { economic indicators }\end{array}$ & $\begin{array}{l}\text { In accordance with the energy company's internal guides } \\
\text { and standards that depend on the kind of energy business }\end{array}$ \\
\hline 10 & Draft a summary & $\begin{array}{l}\text { To complete a comprehensive appraisal of an investment } \\
\text { project, a brief summary is compiled that formalizes the } \\
\text { calculated results for informed decision making. } \\
\text { The summary structure has the following sections: } \\
\text { - General information. } \\
\text { - Project evaluation alternatives depending on technical } \\
\text { solutions. } \\
\text { - Economic effectiveness evaluation. } \\
\text { - Risk assessment. } \\
\text { - Preliminary conclusions about the feasibility of the } \\
\text { project. }\end{array}$ \\
\hline
\end{tabular}

The asset portfolio of PJSC Rosseti includes 35 subsidiaries and affiliates, including 15 interregional and a main network company. The controlling shareholder of the company is the state represented by the Federal Agency for State Property Management of the Russian Federation, which owns $88.04 \%$ of the share capital.

Rosseti Ural, a subsidiary of Rosseti, is a grid operator that transports electric energy via 0.4-220 kV power lines and connects consumers to the network in Sverdlovsk and Chelyabinsk oblasts and Perm Krai. Rosseti Ural operates: 
- $\quad 0.4-220 \mathrm{kV}$-aerial power lines $(122,700 \mathrm{~km})$.

- $\quad 0.4-110 \mathrm{kV}$-cable power lines $(7,244 \mathrm{~km})$.

- $1,0493522 \mathrm{kV}$ substations with total capacity 21,863 MVA.

- $31,8646-10(35) / 0.4 \mathrm{kV}$ transformer substations with total capacity 9,228 MVA.

\subsection{Brief description of substation retrofit project}

A retrofit project for a $110 / 35 / 10-\mathrm{kV}$ substation was selected as a test case for the evaluation method. The investment project is aimed at (1) replacing worn-out equipment; (2) optimization of switchyard layout; (3) improving controllability and observability; (4) increasing the reliability of distribution network; (5) reducing the number of emergency shutdowns.

As part of the project, the following works are to be executed:

- Replacement of transformers.

- Redesign of $110 \mathrm{kV}$ switchyard arrangement in line with layout standards.

- $35 \mathrm{kV}$ switchyard reconstruction.

- Installation of $10 \mathrm{kV}$ indoor switchgear.

- Installation of a battery bank.

As per the Rosseti internal guidelines and methodologies, the current technical condition index of the substation is "deteriorating", and its current failure aftermath index is in the "elevated" range.

The plan is that, as a result of the project implementation, emergency recovery costs would remain the same, but the probability of a hazard occurring would be reduced considerably and the reliability of power supply would increase.

The basic economic data on the project are presented in Table 3. It is supposed that the company would predominantly finance the project with its own funds and use only a minimum amount of borrowed capital.

Table 3: Economic profile of the project.

\begin{tabular}{|l|c|}
\hline \multicolumn{1}{|c|}{ Input data } & Value \\
\hline Total value of facility, million roubles (excl. VAT) & 600 \\
\hline Other expenditures, million roubles (excl. VAT) & 109.9 \\
\hline Depreciation period, years & 30 \\
\hline Maintenance and repair costs, million roubles (excl. VAT) & 0.2 \\
\hline First renovation of facility, years after building's completion & 10 \\
\hline Renovation periodicity, years & $6-12$ \\
\hline Other costs related to facility operation, million roubles (excl. VAT) & 0.003 \\
\hline Frequency of costs, years & Annually \\
\hline Income tax, \% & 20 \\
\hline Property tax, \% & 2.2 \\
\hline Working capital as a percentage of sales, \% & 10 \\
\hline Cost of equity, \% & 11 \\
\hline Share of equity, \% & 100 \\
\hline Average weighted cost of capital, \% & 9 \\
\hline
\end{tabular}




\subsection{Project evaluation using the technique currently adopted by PJSC Rosseti}

To answer the question as to the advisability of applying the newly designed method, the project is initially appraised using the technique currently adopted by Rosseti PJSC. It calculates only two discounted investing metrics: the payback period and net present value, and provides quantitative evaluation of the effects attained by the project.

The calculated discounted metrics of the project are presented in Table 4. The project is estimated to reduce maintenance and repair costs by around 0.01 million roubles a year, while the average annual income from the project would be 138 million roubles.

Table 4: Project evaluation results as per the method adopted by Rosseti.

\begin{tabular}{|l|c|}
\hline Investment metrics & Value \\
\hline Discounted payback period, years & 11 \\
\hline Net present value in 15 years after the launch of the facility, million roubles & 1,026 \\
\hline
\end{tabular}

Among the drawbacks of the adopted evaluation technique is that:

- A limited choice of metrics is calculated.

- The results are presented in a table form only without any interpretation.

- It lacks a general structure and conclusions.

The authors believe that the limitations of the evaluation technique are due to the predominant use of government funding for such projects. In order to raise private funding, a more in-depth and "advanced" evaluation of energy projects is required. In the new method that is described in the following section, the feasibility analysis of a project is structured into phases and the obtained results are pulled together in a summary.

\subsection{Project evaluation: testing of new approach}

This section presents the application of the new method to evaluate the substation retrofit project. The original input data for the project evaluation are supplemented with the required indicators, as shown in Table 5.

Table 5: Additional metrics of project for evaluation as per authors' method.

\begin{tabular}{|c|c|}
\hline \multicolumn{1}{|c|}{ Input data } & Value \\
\hline Macroeconomic data [32] & 6.81 \\
\hline Annual inflation, \% & 19.5 \\
\hline Discount rate, \% & 1,010 \\
\hline Income components [33] & \\
\hline One-rate transmission tariff, rouble/thousand kW h & 1,957 \\
\hline Material costs (compensation for power losses) [33], [34] & 444 \\
\hline Average weighted cost of power losses, roubles/thousand $\mathrm{kW} \mathrm{h}$ &
\end{tabular}

Some stages of the approach, among those listed in Table 2, are omitted in this section that only presets the evaluation results concerning economic and investment calculations and sensitivity analysis of risks (stages seven and eight). Other technical details of the project cannot be disclosed and the calculation of the maximum negative cash balance by scenario 
cannot be performed as part of this paper as this information is kept confidential by the company.

With the additional metrics taken into account, the results of the project evaluation yielded by the new method are presented in Table 6 .

Table 6: Project effectiveness metrics as per new method.

\begin{tabular}{|l|c|}
\hline Metric & Value \\
\hline Net cash flow, million roubles & 5,244 \\
\hline Net present value, million roubles & 34 \\
\hline Internal rate of return, \% & 30.16 \\
\hline Discounted payback period, years & 8 \\
\hline Profitability index & 1.58 \\
\hline Maximum negative cash balance, million roubles & As per scenario \\
\hline
\end{tabular}

The evaluation of the investment metrics showed that the payback period of the project could be reduced from 11 to 8 years thanks to additional evaluation and a more rational approach to borrowing.

One of the supplementary phases of the new method is the assessment of risks on the basis of the sensitivity analysis method. For that purpose, expert assessment was performed of the parameters whose deviation from the baseline value should have a significant impact on the economics of the project. The results of this assessment are presented in Table 7.

Table 7: Estimated elasticity coefficients.

\begin{tabular}{|l|c|c|c|c|}
\hline Variable parameter & $\begin{array}{c}\text { Change in } \\
\text { parameter, \% }\end{array}$ & $\begin{array}{c}\text { Change in NPV, } \\
\text { million roubles }\end{array}$ & $\begin{array}{c}\text { Change in } \\
\text { NPV, \% }\end{array}$ & $\begin{array}{c}\text { Elasticity } \\
\text { coefficient }\end{array}$ \\
\hline Selling price & -10 & 95 & 277 & 27.73 \\
\hline Operating expenditures & +10 & 10 & 28 & 2.80 \\
\hline Sales volume & -10 & 95 & 277 & 27.73 \\
\hline Invested amount & +10 & 91 & 265 & 26.51 \\
\hline Discount rate & +10 & 91 & 263 & 26.35 \\
\hline
\end{tabular}

Single-factor sensitivity analysis was performed for the entirety of economic efficiency metrics. The results of the NPV analysis are depicted by a Tornado diagram (Fig. 1(a)), a sensitivity graph (Fig. 1(b)) and Table 7 with elasticity coefficients.

As a result of single-factor analysis, parameters were identified whose deviation from the baseline values have the greatest impact on the effectiveness of the project. These are price and sales volume.

Multi-factor analysis of sensitivity made it possible to take into account the impact that possible combinations of the key parameters could have on the project. The approach was used to obtain estimations for project effectiveness metrics under various scenarios. The results are shown in Table 8.

Earlier, it was found that changes in price and sales volume have the biggest impact on the effectiveness of the project. However, the effectiveness parameters remain within the acceptable range of values and the NPV stays positive even when sales volume decreases by $3 \%$, the selling price by $2 \%$ and operating expenditures grow by $5 \%$ (baseline scenario). 


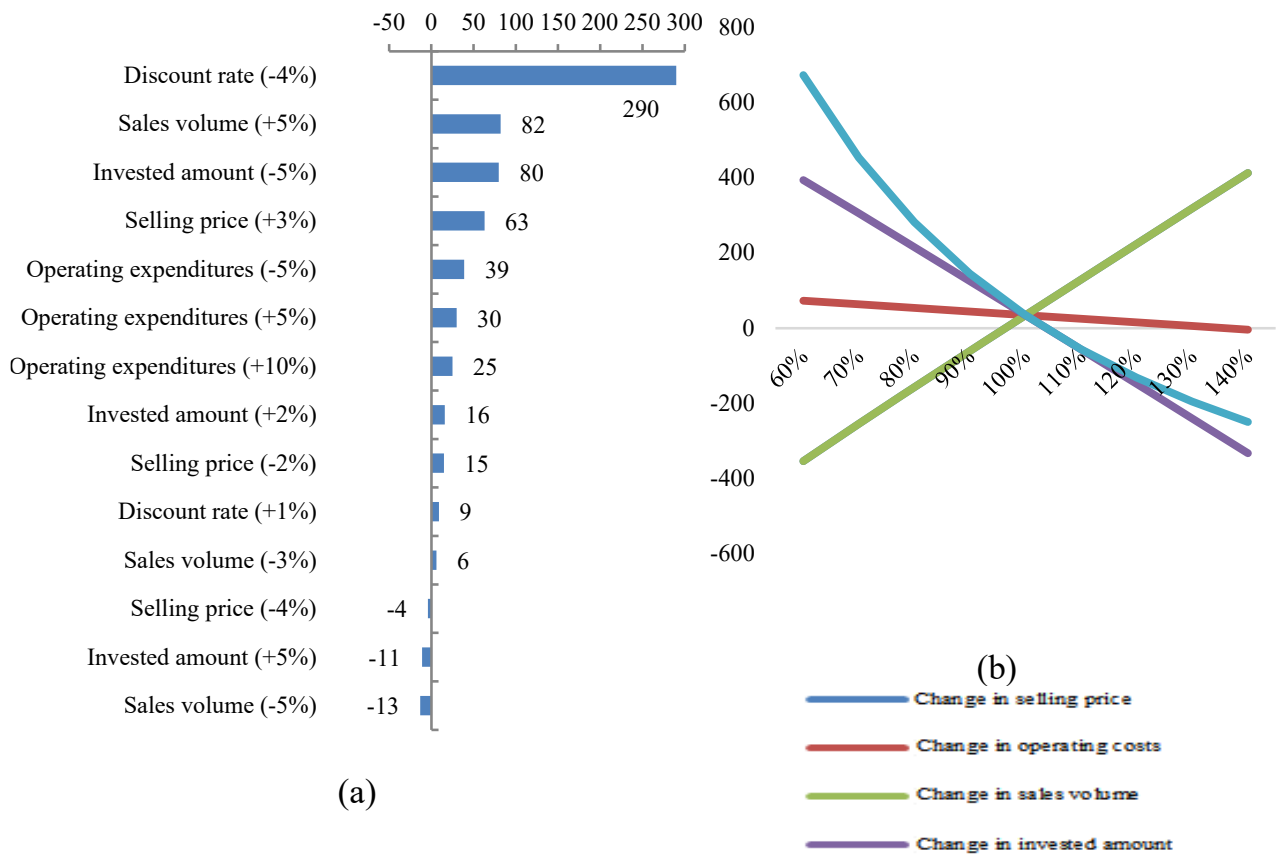

Figure 1: (a) Tornado diagram for NPV, million roubles; and (b) NPV sensitivity graph, million roubles.

Table 8: Multi-factor analysis of sensitivity.

\begin{tabular}{|l|c|c|c|c|}
\hline Key parameters of the project & $\begin{array}{c}\text { Baseline } \\
\text { scenario }\end{array}$ & $\begin{array}{c}\text { Optimistic } \\
\text { scenario }\end{array}$ & $\begin{array}{c}\text { Pessimistic } \\
\text { scenario }\end{array}$ & $\begin{array}{c}\text { Customer's } \\
\text { data }\end{array}$ \\
\hline Change in selling price, \% & -2 & 3 & -4 & 0 \\
\hline Change in operating costs, \% & 5 & -5 & 10 & 0 \\
\hline Change in sales volume, \% & -3 & 5 & -5 & 0 \\
\hline Change in invested amount, \% & 2 & -5 & 5 & 0 \\
\hline Change in discount rate, \% & 1 & -4 & 1 & 0 \\
\hline NPV, million roubles. & 59 & 439 & -149 & 34 \\
\hline IRR, \% & 19 & 23 & 17 & 20 \\
\hline DPP, years & - & 8 & - & 19 \\
\hline PI & 0.94 & 1.50 & 0.85 & 1.04 \\
\hline
\end{tabular}

\section{CONCLUSION}

Today, the majority of energy companies operating in the Russian market use their own approaches to evaluating investment projects. The approaches are based on guidelines that were adopted over 15 years ago [8]-[10]. Furthermore, Russian companies lack sufficient hands-on experience of creating their own approaches to effectiveness appraisal and management that would, among other things, appreciate the specific nature of the industry. 
This article presents a new toolkit for energy project evaluation and describes its trial application in the case of an energy company. The proposed approach takes into account specific features of the energy sector, expands the range of investment metrics and makes it possible to visualize the performed calculations. In order to substantiate the workability of the new approach and improve the objectivity of investing decisions, a comparative analysis was performed of the results delivered by the new method and the one currently in use at Rosseti PJSC. It was shown that the new method makes it possible to thoroughly consider all monetary issues that emerge in the course of the project implementation and to reduce the project's payback period. The advantage of the method is that it produces a detailed, transparent and descriptive evaluation of project effectiveness.

The method has the potential to promote the adoption of a unified approach to investment project evaluation, greater economic effectiveness of an investment program through the selection of the most effective project, and better control over investing efficiency at Rosseti.

For successful adoption of the proposed method by PJSC Rosseti, the following recommendations have been drawn up:

- Formulate assumptions, admissions and requirements regarding the input information, cash flow planning horizons, and scenario conditions that are taken into consideration when calculating project effectiveness.

- Devise a unified list of qualifying qualities for initial grouping of projects.

- Formalize approaches to calculating capital expenditures, operating costs and working capital depending on the phase of the project lifecycle.

- Draft recommendations as to how to evaluate the project income depending on what type the project belongs to under the pre-developed classification.

- Describe the principles of including uncertainty and risk into investment project evaluation.

- Set out requirements for the structure of materials containing economic feasibility studies of projects that are submitted for final examination.

Upon the adoption of the methods, the authors recommend that it should be revised annually to incorporate suggestions put forth by investment experts and up-to-date metrics and method.

\section{ACKNOWLEDGEMENT}

The work was supported by Grant of the President of the Russian Federation (MK4549.2021.2).

\section{REFERENCES}

[1] Chebotareva, G.S. (ed.), Investment Attractiveness of an Energy Generating Company [Investicionnaya privlekatel'nost' energogeneriruyushchej kompanii], Publishing House of the Ural University [Izdatel'stvo Ural'skogo universiteta]: Ekaterinburg, 2017.

[2] Gitelman, L.D. \& Ratnikov, B.E. (eds), Economics and Business in the Electric Power Industry [Ekonomika i biznes v elektroenergetike], Economy [Ekonomika]: Moscow, 2013.

[3] Chebotareva, G., Strielkowski, W. \& Streimikiene, D., Risk assessment in renewable energy projects: A case of Russia. Journal of Cleaner Production, 269, 122110, 2020.

[4] Wang, Q. \& Zhang, F., Does increasing investment in research and development promote economic growth decoupling from carbon emission growth? An empirical analysis of BRICS countries. Journal of Cleaner Production, 252, 119853, 2020. 
[5] Chebotareva, G., Individualization of risks diagnostics in assessment of investment potential of sectoral companies in developing countries. International Journal of Sustainable Development and Planning, 13(6), pp. 851-859, 2018.

[6] Kozlova, M. \& Collan, M., Renewable energy investment attractiveness: Enabling multi-criteria cross-regional analysis from the investors' perspective. Renewable Energy, 150, pp. 382-400, 2020.

[7] Chebotareva, G.S., Personal communication, 1-10 March 2020, Investment Directorate of Branch Rossetti Ural, Ekaterinburg, Russia.

[8] RAO UES, Methodological features of evaluating the effectiveness of projects in the electric power industry [Metodicheskie osobennosti ocenki effektivnosti proektov $\mathrm{v}$ elektroenergetike], 2008. http://docs.cntd.ru/document/1200088779. Accessed on: 1 April 2020.

[9] The Ministry of Economic Development of the Russian Federation, Methodological recommendations for evaluating the effectiveness of investment projects [Metodicheskie rekomendacii po ocenke effektivnosti investicionnyh proektov], 1999. http://docs.cntd.ru/document/1200005634. Accessed on: 1 April 2020

[10] RAO UES, Guidelines for evaluating the effectiveness and development of investment projects and business plans in the electric power industry [Metodicheskie rekomendacii po ocenke effektivnosti i razrabotke investicionnyh proektov i biznesplanov v elektroenergetike], 2008. http://docs.cntd.ru/document/1200088779. Accessed on: 1 April 2020.

[11] Karmaker, A.K., Ahmed, M.R., Hossain, M.A. \& Sikder, M.M., Feasibility assessment and design of hybrid renewable energy based electric vehicle charging station in Bangladesh. Sustainable Cities and Society, 39, pp. 189-202, 2018.

[12] Diemuodeke, E.O., Addo, A., Oko, C.O.C., Mulugetta, Y. \& Ojapah, M.M., Optimal mapping of hybrid renewable energy systems for locations using multi-criteria decision making algorithm. Renewable Energy, 134, pp. 461-477, 2019.

[13] Ghiasi, M., Esmaeilnamazi, S., Ghiasi, R. \& Fathi M., Role of renewable energy sources in evaluating technical and economic efficiency of power quality. Technology and Economics of Smart Grids and Sustainable Energy, 5(1), p. 1, 2020.

[14] Landi, D., Castorani, V. \& Germani, M., Interactive energetic, environmental and economic analysis of renewable hybrid energy system. International Journal on Interactive Design and Manufacturing, 13(3), 885-899, 2019.

[15] Brigham, Y. \& Houston, J. (eds), Financial Management, Piter: Saint-Petersburg, 2007.

[16] Huang, K., Management forecast errors and corporate investment efficiency. Journal of Contemporary Accounting and Economics, 16(3), 100208, 2020.

[17] Blahun, I.S. \& Leshuk, H.V., Probabilistic and statistical methods of risk assessment of investment projects of a region. Austrian Journal of Humanities and Social Sciences, 5(6), pp. 53-59, 2017.

[18] Leshuk, H.V., Monitoring mechanism for investment development of regions' infrastructure. Baltic Journal of Economic Studies, 3(4), pp. 142-150, 2017.

[19] Dayananda, D., Irons, R., Harrison, S., Herbohn, J., Rowland, P. \& Rowland P. (eds), Capital Budgeting: Financial Appraisal of Investment Projects, Cambridge University Press: Cambridge, 2002.

[20] Baker, H.K. \& English, P. (eds), Capital Budgeting Valuation: Financial Analysis for Today's Investment Projects, John Wiley \& Sons: New Jersey, 2011.

[21] Glukhova, M.G. \& Varlamova, O.A., Features of foreign experience of economic evaluation of investment projects [Osobennosti zarubezhnogo opyta ekonomicheskoj 
ocenki investicionnyh proektov]. Economy: Yesterday, Today, Tomorrow [Ekonomika: vchera, segodnya, zavtra], 7, pp. 47-57, 2016.

[22] Goldman Sachs, Goldman Sachs is changing the evaluation of the effectiveness [Goldman Sachs menyaet ocenku effektivnosti], 2016. https://www.vedomosti.ru/ management/articles/2016/06/02/643309-goldman-sachs-menyaet-otsenkueffektivnosti-36-500-sotrudnikov Accessed on: 1 April 2020.

[23] Behrens, W. \& Hawranek, P.M. (eds), Manual for the Preparation of Industrial Feasibility Studies, United Nations: New York, 1978.

[24] Livshits, V.N., Project analysis: Methodology adopted by the World Bank [Proektnyj analiz: metodologiya, prinyataya vo Vsemirnom banke]. Economics and Mathematical Methods [Ekonomika i matematicheskie metody], 3, pp. 37-50, 1994.

[25] Levin, H.M. \& McEwan, P.J. (eds), Cost Effectiveness Analysis: Methods and Applications, SAGE Publications, 2001.

[26] Dosuzheva, E.E., Models for evaluating the commercial effectiveness of innovation and investment projects [Modeli ocenki kommercheskoj effektivnosti innovacionnoinvesticionnyh proektov]. Naukovedenie [Naukovedenie], 7(3), pp. 2-33, 2015.

[27] Novikova, T.S., Methods for analyzing the effectiveness of projects to justify state support [Metody analiza effektivnosti proektov dlya obosnovaniya gosudarstvennoj podderzhki]. Bulletin of Novosibirsk State University [Vestnik Novosibirskogo gosudarstvennogo universiteta], 9(2), pp. 45-55, 2009.

[28] Vilensky, P.L., Livshits, V.N., Smolyak, A.G. \& Shakhnazarov, S.A., On the methodology for evaluating the effectiveness of real investment projects [O metodologii ocenki effektivnosti real'nyh investicionnyh proektov]. Russian Economic Journal [Rossijskij ekonomicheskij zhurnal], 9(10), pp. 63-73, 2006.

[29] Novikova, T.S., Methods for evaluating the effectiveness of innovative projects [Metody ocenki effektivnosti innovacionnyh proektov]. Innovative Potential of the Scientific Center: Methodological and Methodological Problems of Analysis and Evaluation [Innovacionnyj potencial nauchnogo centra: metodologicheskie $i$ metodicheskie problemy analiza i ocenki], 1, pp. 40-63, 2007.

[30] Koksharov V.A. (ed.), Regional Energy Consumption Management: Theory and Methodology [Upravlenie energopotrebleniem regiona: teoriya i metodologiya], LAP Academic Publishing: Saarbrücken, 2012.

[31] PJSC Rosseti, Official site, 2020. http://www.rosseti.ru/. Accessed on: 26 May 2020.

[32] Ministry of Economic Development of the Russian Federation, Forecast of socioeconomic development of the Russian Federation for 2017 and for the planning period of 2018 and 2019 [Prognoz social'no-ekonomicheskogo razvitiya Rossijskoj Federacii na 2017 god i na planovyj period 2018 i 2019 godov], 2017. https://www.garant.ru/ products/ipo/prime/doc/71477706/. Accessed on: 10 April 2020.

[33] Rossetti Ural, Offers on the amount of prices (tariffs) for services [Predlozheniya o razmere cen (tarifov) na uslugi], 2019. https://www.mrsk-ural.ru/disclosure/ monopoly/project/. Accessed on: 10 April 2020.

[34] Ministry of Energy of the Russian Federation, About the organization in the Ministry of Energy of the Russian Federation of work on approval of standards of technological losses of the electric power at its transfer on electric networks [Ob organizacii $\mathrm{v}$ Ministerstve energetiki Rossijskoj Federacii raboty po utverzhdeniyu normativov tekhnologicheskih poter' elektroenergii pri ee peredache po elektricheskim setyam], 2008. https://base.garant.ru/195516/. Accessed on: 10 April 2020.

[35] Rossetti Ural, Annual report [Godovoj otchet Rosseti Ural], 2019. https://www.mrskural.ru/disclosure/issuer/annual-reports/. Accessed on: 10 May 2020. 